\title{
ECONOMIC CONDITIONS OF THE STATES BEFORE AND AFTER THE AMERICAN CIVIL WAR
}

\author{
Vasanthakumar N. Bhat \\ Management Department, Pace University, New York, NY, USA
}

Received 2014-07-30; Revised 2014-10-08; Accepted 2014-10-16

\begin{abstract}
Even though, the American Civil War is considered as a seminal event in the history of the United States, there are not many empirical studies examining economic conditions of the Union and the Confederate states. Even though, economic conflict is not considered to be a cause of the Civil War, economic conditions after the war were vastly different in the Union and the Confederate states. The purpose of this study is to analyze the economic outcomes of individuals in the Confederate states and the Union states before and after the American Civil War using census data for 1860 and 1880. Our goal is to analyze the improvements in the occupation income scores. Since the slaves were freed, we also examine whether there was a reduction in the farm households.
\end{abstract}

Keywords: The American Civil War, Census, Confederate States, Occupational Income Score

\section{INTRODUCTION}

The American Civil War is an event of significant economic impact in the American history. The war resulted in the abolition of slavery in the Southern states and preservation of the Union. The issues relating to slavery, trade and tariffs and state's rights were causing divisions between the Northern and the Southern states before the Civil War. The economic divisions with the Northern states with growing manufacturing sector and small farms using free labor and the Southern states with large farms using slave labor aggravated the situation. When the Northern states wanted to ban slavery in the Western Territories that would become new states, the Southern states feared that such a move would eventually result in the abolition of slavery and loss of their valuable assets in the form of the slaves. The American Civil War began with the secession of the Southern states, South Carolina, Mississippi, Florida, Alabama, Georgia, Louisiana, Texas, Virginia, Arkansas, Tennessee and North Carolina, in the sequential order, from the Union in 1860-61. The war ended in 1865 with death of more than 750,000 people (Hacker, 2011) and destruction of the South's infrastructure. Even though there is a vast literature on the economic impact of the civil war, most studies focus at the macroeconomic level. The purpose of this study is to examine the impact at the individual level using census data.

\section{LITERATURE REVIEW}

The American Civil War has been examined in detail. Therefore, we will only discuss literature relevant to this study. According to Beard and Beard (1927), the defeat of the agricultural South resulted in the "rise of capitalism". Hacker (1940) also comes to the same conclusion. However, his thesis is that the victory of the Northern states provided the industrialist-capitalist class clout to pass legislation that resulted in "the triumph of American capitalism." (Goldin and Lewis, 1975). In short, both Charles and Mary Beard and Hacker conclude that even though the Civil War caused extensive damages, it also generated net benefits because of subsequent high growth. However, Cochran (1961), Salsbury (1967; Engerman, 1966) challenge these views. Cochran, for example, finds that the growth in value added from 1839 to 1859 are similar to those from 1869 to 1889. Engerman (1966) finds that commodity output growth between 1870 and 1900 was similar to that 
between 1840 and 1860. Engerman (1966) also finds no basis for the claim that US economic activity took off after the war based on Gallman (1966) GNP estimates. Therefore, we may conclude that the Civil War was not a defining moment as Beards and Hacker have claimed.

Even though, the census data has been an extensive source for micro-level analysis, there are not many studies that analyze the Civil War using census data. Hacker (2011) uses it to estimate the number of Civil War dead. Jaworski (2009) uses linked sample of census data for 1850 and 1870 to examine wealth buildup and concludes that wealth accumulation was significant in the Southern states in the 1850's and sluggish in the 1860's. His findings also include that white-collar professionals and blue-collar workers benefitted enormously between 1850 and 1870 and farmers suffered after the war. Steckel (1989) uses it to examine incomes between 1850 and 1860. According to Ransom and Sutch (2001), even though industrial sector in the Southern states grew after the war, rebound in the agricultural sector was sluggish because of abolition of slavery.

There is also a vast literature on the impact of civil war in other countries. A comprehensive review of the literature on the costs of civil war in various countries can be found in the WB (2003). The literature on the consequences of civil war can be categorized based on economic, health and other impacts. According to Collier and Hoeffler (1998), initial income, ethnolinguistic fractionalization, the amount of natural resources and initial population are four major determinants of the duration and probability of civil wars. Fosu and Collier (2005) examine post conflict situations particularly in Sub-Saharan Africa with the emphasis on policies that either maintain or end peace. According to Murdoch and Sandler (2004), civil wars reduce the economic growth of the neighboring countries and regions. Organski and Kugler (1981), based on an analysis of economic impacts of both world wars on European countries, find that the effect of wars wear out and both winners and losers return to pre-war growth levels in 15-20 years. According to Barro and Sala-i-Martin (1995), based on the analysis of post-war Japan and Germany, assert that when wars adversely impacts one factor of production compared to others, the return on other factors rise resulting in rapid economic growth. Przeworski et al. (2000), based on an empirical study, conclude that post-war economic growth was significant. Djankov et al. (2005) after examining the impact of U.S. bombing in various districts in Vietnam did not find any lasting negative impact on poverty rates, consumption levels, infrastructure, literacy, or population density, According to Ghobarah et al. (2003), civil wars increase deaths and disability because of contagious diseases. Soares (2006) estimates the consequences of violence in terms of life-expectancy and as a percentage of GDP. Montalvo and Reynal-Querol (2007) examine the impacton the incidence of malaria in countries receiving refugees from civil war countries. Based on a cross-country analysis, Przeworski et al. (2000) find that five-year average economic growth following a war is $5.98 \%$ per year. According to them, even though damages under dictatorships are more than damages under democracies, recoveries are also faster under dictatorships than under democracies.

\section{OBJECTIVES}

Even though, an immediate impact of the American civil war has been expansive, the long-term impact is not clear. Our goal is to examine extent of improvement in economic conditions of individuals before and after the civil war. We measure the benefits in terms of the value of personal property. Personal property presents "the contemporary dollar value of all stocks, bonds, mortgages, notes, livestock, plate, jewels and furniture owned by the respondents." We also examine trends in farm households. Since the slaves who typically worked in the farms were freed, we examine the impact of the civil war on the changes in farm workers.

\section{METHODOLOGY}

We use $1 \%$ samples of the decades ending 1850 , 1860, 1870 and 1880 of U.S. Census data. (Ruggles et al., 2010). We categorize states into the Confederate, the Slave and the Union states. The Confederate states include South Carolina (SC), Mississippi (MS), Florida (FL), Alabama (AL), Georgia (GA), Louisiana (LA), Texas (TX), Virginia (VA), Arkansas (AR), North Carolina (NC) and Tennessee (TN). The Slave states include Delaware (DE), Missouri (MO), Maryland (MD) and Kentucky (KY). Pennsylvania (PA), New Jersey (NJ), Connecticut (CT), Massachusetts (MA), New Hampshire (NH), New York (NY), Rhode Island (RI), Vermont (VT), Ohio (OH), Indiana (IN), Illinois (IL), Maine (ME), Michigan (MI), Iowa, (IA), Wisconsin (WI), California (CA), Oregon (OR) and Minnesota $(\mathrm{MN})$ are categorized as the Union States. Since the census data of 1850 and 1860 did not count the slaves, we do analysis only for the white population. However, we presented data for the blacks for comparison purposes. We also used linked sample files of censuses. 
However, linked file was available for only 1860-1880 period. Since the life expectancy of the whites were 39.5 years and 23 years for the blacks in 1850, the linked file data accounted for only a small proportion of the population (Haines (2000)).

\section{ANALYSIS OF RESULTS}

The continuing conflict between the Southern and the Northern states several decades before the Civil War made it impossible for the federal government to implement coherent national policy. Secession of the Southern states and resignation of legislators from the Congress provided the Northern states an opportunity to enact legislation favorable to them while fighting the Civil War. In addition, the victory in the Civil War ensured continuous control of the Congress by the Northern states. According to Russell (2001), four legislations enacted during the Civil War impacted the development of the Northern States subsequent to the War. The Morrill Tariff of 1861 substantially increased tariff rates putting an end to the declining rates during more than previous thirty years. The Transcontinental Railroad Act of 1862 made it possible to finance three transcontinental railroads that helped Northern states significantly. The Morrill Land Grant Act of 1862 established agricultural and mechanical colleges in each state that remained in the Union by the allocation of 30,000 acres of land. The National Bank Act of 1863 formulated standards for banking system. The Homestead Act of 1862 encouraged settlement in western territories by providing 160 acres of land to those who move and settle in the western territories for more than 5 year and declare intention to become a citizen. These enactments had far reaching effect on the economies of the Northern states.

Economic development subsequent to the Civil War was impacted significantly by the devastation of infrastructure in the Southern states. The Confederate currency held by the Southerners became worthless as a result of losing the Civil War. The major assets held by the people in the form of slaves were lost as a result of the war. The destruction of banks also reduced the ability to finance businesses. These impoverished most Southern people.

In Table 1, population by race is presented for 1850 , 1860, 1870 and 1880. The percentage of white population in the Confederate states to the total US white population before the Civil War were $21 \%$ in 1850 and $19.2 \%$ in 1860 . However, in 1870 , percent fell to 17.1 . In 1880 , percent of the Confederate white population to the total white population was $18.6 \%$ and did not recover to pre-civil war level. As a result of poor economies in the South, fewer immigrants moved to the South. Even though total white population grew by $23 \%$ in 1860 and 1870 , growth in the Confederate states was only $10 \%$. It could be because of war deaths and also because of fewer immigrants. However, during 1870-1880, population grew by $38 \%$ compared to $26 \%$ for the total population. Since only the blacks were included in the 1850 and 1860 censuses, their numbers were very low in 1850 and 1850. However, they were freed and were included in 1870 and 1880 censuses, their numbers grew substantially based on the 1870 and 1880 censuses. Based on Table 1, the blacks constituted about $41 \%$ of the population of the Confederate states in 1870 and 1880. In the Slave States, the blacks accounted for only about 13.7 and $13.6 \%$ of the total population in 1870 and 1880. On the other hand, the blacks constituted meagre 1.4 and $1.5 \%$ of the total population in 1870 and 1880 .

\subsection{Impact on Farming}

According to Hacker (2011), 750,000 died during the Civil War. This represents 1 in 10 white men of military age in 1860 . The death rates among the Southern men were higher. According to the Hacker (2011) estimate, $22.6 \%$ of white males in the age group 20-24 lost their lives because of the war. This dramatically reduced workforce available for farming. In addition, the slaves who typically worked in the farms were no more freely available. Therefore, we examine the impact of the Civil War on farming. According to Table 2, percent of white males involved in farming in 1850 and 1860 were 66.95 and $62.3 \%$ respectively. However, in 1870 it fell to $59.2 \%$. In 1880 , it went back to 65.4 approximately the same level it was in 1860 . On the other hand, in the Slave states, the percent population involved in farming was $59 \%$ in 1850 , fell to $55 \%$ in 1860 , further fell to $51 \%$ in 1870 and rose very little to $53 \%$ in 1880 . An examination of percent of total population involved in farming in the Confederate states indicate that the percent in 1850 of 65.9 fell to $61.2 \%$ in 1860 , then plummeted to $45.1 \%$ in 1870 and then rose to $56 \%$ in 1870. Clearly, immediately after the Civil War, even though the slaves were freed, they were not able to get into farming. However, during 1870 to 1880 period, the participation of both the whites and the blacks in farming increased substantially in the Confederate states and white male participation reached the same level as in 1850. The number of the blacks involved in farming rose from about 1 million in 1870 to 2.27 million in 1880 . The impact of the Civil War in the Slave states and the Union states were not that significant as the slaves constituted only a small portion of the population. 
Table 1. Population by race

\begin{tabular}{|c|c|c|c|c|c|c|}
\hline \multirow{2}{*}{\multicolumn{2}{|c|}{ Race [general version] }} & & \multicolumn{4}{|l|}{ Census year } \\
\hline & & & \multirow{2}{*}{$\frac{1850}{4,076,227}$} & \multirow{3}{*}{$\begin{array}{l}1860 \\
5,067,682 \\
24 \%\end{array}$} & \multirow{3}{*}{$\begin{array}{l}1870 \\
5,558,124 \\
10 \%\end{array}$} & \multirow{3}{*}{$\begin{array}{l}1880 \\
7,651,219 \\
38 \%\end{array}$} \\
\hline White & Confederate states & Count & & & & \\
\hline & & $\%$ change & & & & \\
\hline & & $\%$ within Census year & $21.00 \%$ & $19.20 \%$ & $17.10 \%$ & $18.60 \%$ \\
\hline & Slave state (excconf) & Count & $1,835,748$ & $2,586,057$ & $3,397,993$ & $4,232,080$ \\
\hline & & $\%$ change & & $41 \%$ & $31 \%$ & $25 \%$ \\
\hline & & $\%$ within Census year & $9.40 \%$ & $9.80 \%$ & $10.40 \%$ & $10.30 \%$ \\
\hline & Union states & Count & $13,523,370$ & $18,776,542$ & $23,631,821$ & $29,211,647$ \\
\hline & & $\%$ change & & $39 \%$ & $26 \%$ & $24 \%$ \\
\hline & & $\%$ within Census year & $69.60 \%$ & $71.00 \%$ & $72.50 \%$ & $71.10 \%$ \\
\hline & & Count & $19,435,345$ & $26,430,281$ & $32,587,938$ & $41,094,946$ \\
\hline & & $\%$ change & & $36 \%$ & $23 \%$ & $26 \%$ \\
\hline & & $\%$ within Census year & $100.00 \%$ & $100.00 \%$ & $100.00 \%$ & $100.00 \%$ \\
\hline \multirow[t]{12}{*}{ Black } & Confederate state & Count & 106,517 & 129,068 & $3,902,289$ & $5,331,240$ \\
\hline & & $\%$ change & & $21 \%$ & $2923 \%$ & $37 \%$ \\
\hline & & $\%$ within Census year & $24.90 \%$ & $28.20 \%$ & $81.50 \%$ & $82.80 \%$ \\
\hline & Slave state (excconf) & Count & 112,103 & 112,726 & 539,568 & 666,016 \\
\hline & & $\%$ change & & $1 \%$ & $379 \%$ & $23 \%$ \\
\hline & & $\%$ within Census year & $26.20 \%$ & $24.60 \%$ & $11.30 \%$ & $10.30 \%$ \\
\hline & Union states & Count & 209,425 & 216,291 & 344,404 & 442,020 \\
\hline & & $\%$ change & & $3 \%$ & $59 \%$ & $28 \%$ \\
\hline & & $\%$ within Census year & $48.90 \%$ & $47.20 \%$ & $7.20 \%$ & $6.90 \%$ \\
\hline & & Count & 428,045 & 458,085 & $4,786,261$ & $6,439,276$ \\
\hline & & $\%$ change & & $7 \%$ & $945 \%$ & $35 \%$ \\
\hline & & $\%$ within Census year & $100.00 \%$ & $100.00 \%$ & $100.00 \%$ & $100.00 \%$ \\
\hline
\end{tabular}

Table 2. Population involved in Farming by Census year

\begin{tabular}{|c|c|c|c|c|c|}
\hline State & & 1850 & 1860 & 1870 & 1880 \\
\hline \multicolumn{6}{|l|}{ The Whites } \\
\hline \multirow[t]{3}{*}{ Confederate state } & Count & 2728968 & 3156625 & 3288645 & 5002698 \\
\hline & $\%$ farming & $66.95 \%$ & $62.29 \%$ & $59.17 \%$ & $65.38 \%$ \\
\hline & $\%$ change & & $15.67 \%$ & $4.18 \%$ & $52.12 \%$ \\
\hline \multirow[t]{3}{*}{ Slave state (excconf) } & Count & 1085564 & 1424365 & 1747674 & 2236566 \\
\hline & $\%$ farming & $59.13 \%$ & $55.08 \%$ & $51.43 \%$ & $52.85 \%$ \\
\hline & $\%$ change & & $31.21 \%$ & $22.70 \%$ & $27.97 \%$ \\
\hline \multirow{3}{*}{ Union states } & Count & 6580097 & 8151491 & 9107965 & 10525505 \\
\hline & $\%$ farming & $48.66 \%$ & $43.41 \%$ & $38.54 \%$ & $36.03 \%$ \\
\hline & $\%$ change & & $23.88 \%$ & $11.73 \%$ & $15.56 \%$ \\
\hline \multirow[t]{3}{*}{ Total } & Count & 10394629 & 12732481 & 14144284 & 17764769 \\
\hline & $\%$ farming & $53.48 \%$ & $48.17 \%$ & $43.40 \%$ & $43.23 \%$ \\
\hline & $\%$ change & & $22.49 \%$ & $11.09 \%$ & $25.60 \%$ \\
\hline \multicolumn{6}{|l|}{ Total } \\
\hline \multirow[t]{3}{*}{ Confederate state } & Count & 2754420 & 3183512 & 4266463 & 7269026 \\
\hline & $\%$ farming & $65.90 \%$ & $61.20 \%$ & $45.10 \%$ & $56.00 \%$ \\
\hline & $\%$ change & & $15.58 \%$ & $34.02 \%$ & $70.38 \%$ \\
\hline \multirow[t]{3}{*}{ Slave state (excconf) } & Count & 1107936 & 1449173 & 1884428 & 2414540 \\
\hline & $\%$ farming & $56.90 \%$ & $53.70 \%$ & $47.90 \%$ & $49.30 \%$ \\
\hline & $\%$ change & & $30.80 \%$ & $30.03 \%$ & $28.13 \%$ \\
\hline \multirow[t]{3}{*}{ Union states } & Count & 6618895 & 8193049 & 9171392 & 10600140 \\
\hline & $\%$ farming & $48.20 \%$ & $43.00 \%$ & $38.10 \%$ & $35.60 \%$ \\
\hline & $\%$ change & & $23.78 \%$ & $11.94 \%$ & $15.58 \%$ \\
\hline \multirow[t]{3}{*}{ Total } & Count & 10481251 & 12825734 & 15322283 & 20283706 \\
\hline & $\%$ farming & $52.80 \%$ & $47.60 \%$ & $40.90 \%$ & $42.60 \%$ \\
\hline & $\%$ change & & $22.37 \%$ & $19.47 \%$ & $32.38 \%$ \\
\hline
\end{tabular}


In Table 3, we present occupations of the Whites over 15 years of age by census year. More than $53 \%$ of the whites were dependent on agriculture for their livelihood in 1860 in the Confederate states and it rose to $65 \%$ in 1860. However, in the Union states, the percent of the whites involved in agriculture fell from $41.1 \%$ in 1860 to $34.4 \%$ in 1880 clearly indicating job opportunities in other sectors including manufacture, trade and transportation.

\subsection{Impact on the Personal Property}

In Table 4 and 5, we present an analysis of personal property. The census data relating to personal wealth were available only for years 1860 and 1870 . The data for 1860 included the value of the slaves. Based on the Table 4, every age group in the Confederate statesand the Slave states lost personal property during 1860 and 1870 and the loss was substantial representing more than $83 \%$ of assets held in 1860 for the Confederate states and $27.7 \%$ in the Slave states. This is consistent with the observation that the Confederate states had $41 \%$ of their population black and the Slave states $13.2 \%$. During the same period, every age group in the Union states increased their personal property by about $62 \%$.

In Table 5, we present a Tobit regression analysis of personal properties for 1860 and 1870 separately. Our goal is to compare the personal estate of the Whites in 1860 and 1870 in the Confederate, the Slave and the the Union states after accounting for age group, occupational industry and occupational score. Based on the positive sign for the occupational score, it is obvious that in both years, people holding higher incomes jobs continue to maintain higher personal estate. In other words, people holding high income jobs were having more assets compared to people holding low paying jobs. Typically, people with age less than 39 years had less personal assets than people over 39 in 1860 as well as 1870 . Compared to people not in labor force, people involved in agriculture had more assets. In comparison to the Union States, people in the Slave states and the Confederate states had greater amounts of personal properties in 1860 after accounting for age, occupational sector and occupational income score. On an average, a person in the Confederate states had $\$ 3256.4$ and the Slave states $\$ 924.3$ more in assets in comparison to a person in the Union States in 1860. However, it all changed in 1870. A person in the Confederate states had $\$ 59.99$ less assets compared to a person in the Union states in 1870. A person in the Slave states did not suffer to the same extent. A person in the Slave states had $\$ 13.13$ more in assets in comparison to a person in the Union states.

Table 3. Occupations for the whites over 15 of age by census year

\begin{tabular}{|c|c|c|c|c|c|c|c|c|c|c|c|c|c|}
\hline & & \multicolumn{3}{|l|}{1850} & \multicolumn{3}{|l|}{1860} & \multicolumn{3}{|l|}{1870} & \multicolumn{3}{|l|}{1880} \\
\hline & & $\begin{array}{l}\text { Confederate } \\
\text { state }\end{array}$ & $\begin{array}{l}\text { Slave states } \\
\text { (excconf) }\end{array}$ & $\begin{array}{l}\text { Union } \\
\text { states }\end{array}$ & $\begin{array}{l}\text { Confederate } \\
\text { state }\end{array}$ & $\begin{array}{l}\text { Slave state } \\
\text { (excconf) }\end{array}$ & $\begin{array}{l}\text { Union } \\
\text { states }\end{array}$ & $\begin{array}{l}\text { Confederate } \\
\text { state }\end{array}$ & $\begin{array}{l}\text { Slave state } \\
\text { (excconf) }\end{array}$ & $\begin{array}{l}\text { Union } \\
\text { states }\end{array}$ & $\begin{array}{l}\text { Confederate } \\
\text { state }\end{array}$ & $\begin{array}{l}\text { Slave state } \\
\text { (excconf) }\end{array}$ & $\begin{array}{l}\text { Union } \\
\text { states }\end{array}$ \\
\hline \multirow[t]{2}{*}{ Not reported } & Count & 96910 & 48780 & 442068 & 109067 & 55045 & 468986 & 42418 & 62525 & 577920 & 119973 & 89608 & 1028304 \\
\hline & $\%$ within & $9.4 \%$ & $9.9 \%$ & $11.6 \%$ & $8.3 \%$ & $7.7 \%$ & $8.8 \%$ & $3.0 \%$ & $6.8 \%$ & $8.5 \%$ & $5.9 \%$ & $7.5 \%$ & $11.6 \%$ \\
\hline \multirow[t]{2}{*}{ Agriculture } & Count & 599950 & 241088 & 1567405 & 697759 & 338928 & 2116022 & 925195 & 461830 & 2616048 & 1329122 & 581144 & 3060569 \\
\hline & $\%$ within & $58.0 \%$ & $49.0 \%$ & $41.1 \%$ & $53.1 \%$ & $47.5 \%$ & $39.6 \%$ & $64.8 \%$ & $50.3 \%$ & $38.4 \%$ & $65.0 \%$ & $48.9 \%$ & $34.4 \%$ \\
\hline \multirow{4}{*}{$\begin{array}{l}\text { Forestry and } \\
\text { fishing } \\
\text { Mining, } \\
\text { quarrying, oil } \\
\text { extraction }\end{array}$} & Count & 929 & 382 & 8608 & 3945 & 752 & 13266 & 2527 & 955 & 16389 & 6166 & 1172 & 23372 \\
\hline & $\%$ within & $.1 \%$ & $.1 \%$ & $.2 \%$ & $.3 \%$ & $.1 \%$ & $.2 \%$ & $.2 \%$ & $.1 \%$ & $.2 \%$ & $.3 \%$ & $.1 \%$ & $.3 \%$ \\
\hline & Count & 795 & 2045 & 80697 & 1563 & 5326 & 97881 & 3742 & 5821 & 116006 & 4731 & 14431 & 154393 \\
\hline & $\%$ within & $.1 \%$ & $.4 \%$ & $2.1 \%$ & $.1 \%$ & $.7 \%$ & $1.8 \%$ & $.3 \%$ & $.6 \%$ & $1.7 \%$ & $.2 \%$ & $1.2 \%$ & $1.7 \%$ \\
\hline \multirow[t]{2}{*}{ Construction } & Count & 34100 & 24085 & 228302 & 46807 & 36637 & 317487 & 37727 & 45335 & 449852 & 51994 & 52792 & 497487 \\
\hline & $\%$ within & $3.3 \%$ & $4.9 \%$ & $6.0 \%$ & $3.6 \%$ & $5.1 \%$ & $5.9 \%$ & $2.6 \%$ & $4.9 \%$ & $6.6 \%$ & $2.5 \%$ & $4.4 \%$ & $5.6 \%$ \\
\hline \multirow[t]{2}{*}{ Manufacture } & Count & 23827 & 20682 & 228967 & 31087 & 33977 & 335746 & 35230 & 46626 & 541697 & 40519 & 61841 & 710881 \\
\hline & $\%$ within & $2.3 \%$ & $4.2 \%$ & $6.0 \%$ & $2.4 \%$ & $4.8 \%$ & $6.3 \%$ & $2.5 \%$ & $5.1 \%$ & $7.9 \%$ & $2.0 \%$ & $5.2 \%$ & $8.0 \%$ \\
\hline \multirow[t]{2}{*}{ Trade } & Count & 91269 & 55907 & 572228 & 122679 & 85429 & 790620 & 130322 & 117038 & 1055308 & 180437 & 167144 & 1553071 \\
\hline & $\%$ within & $8.8 \%$ & $11.4 \%$ & $15.0 \%$ & $9.3 \%$ & $12.0 \%$ & $14.8 \%$ & $9.1 \%$ & $12.8 \%$ & $15.5 \%$ & $8.8 \%$ & $14.1 \%$ & $17.4 \%$ \\
\hline \multirow[t]{2}{*}{ Transportation } & Count & 13865 & 15357 & 121475 & 28050 & 21774 & 193732 & 29674 & 37772 & 336829 & 42412 & 47107 & 468336 \\
\hline & $\%$ within & $1.3 \%$ & $3.1 \%$ & $3.2 \%$ & $2.1 \%$ & $3.1 \%$ & $3.6 \%$ & $2.1 \%$ & $4.1 \%$ & $4.9 \%$ & $2.1 \%$ & $4.0 \%$ & $5.3 \%$ \\
\hline \multirow{4}{*}{$\begin{array}{l}\text { Utilities (water, } \\
\text { tgraphetc } \\
\text { Services }\end{array}$} & Count & 0 & 566 & 959 & 206 & 50 & 1791 & 1007 & 1197 & 9991 & 2312 & 1652 & 23671 \\
\hline & $\%$ within & $.0 \%$ & $.1 \%$ & $.0 \%$ & $.0 \%$ & $.0 \%$ & $.0 \%$ & $.1 \%$ & $.1 \%$ & $.1 \%$ & $.1 \%$ & $.1 \%$ & $.3 \%$ \\
\hline & Count & 60958 & 28091 & 204189 & 88305 & 43235 & 305089 & 71957 & 50858 & 398350 & 98992 & 73746 & 585330 \\
\hline & $\%$ within & $5.9 \%$ & $5.7 \%$ & $5.4 \%$ & $6.7 \%$ & $6.1 \%$ & $5.7 \%$ & $5.0 \%$ & $5.5 \%$ & $5.8 \%$ & $4.8 \%$ & $6.2 \%$ & $6.6 \%$ \\
\hline \multirow{4}{*}{$\begin{array}{l}\text { Public Admn } \\
\text { and Post office } \\
\text { Non-classified }\end{array}$} & Count & 8088 & 3150 & 15503 & 10461 & 4506 & 26992 & 14995 & 7843 & 51894 & 20166 & 10019 & 72214 \\
\hline & $\%$ within & $.8 \%$ & $.6 \%$ & $.4 \%$ & $.8 \%$ & $.6 \%$ & $.5 \%$ & $1.1 \%$ & $.9 \%$ & $.8 \%$ & $1.0 \%$ & $.8 \%$ & $.8 \%$ \\
\hline & Count & 848 & 197 & 2381 & 17409 & 10099 & 145692 & 7498 & 7160 & 103317 & 2427 & 2153 & 39439 \\
\hline & $\%$ within & $.1 \%$ & $.0 \%$ & $.1 \%$ & $1.3 \%$ & $1.4 \%$ & $2.7 \%$ & $.5 \%$ & $.8 \%$ & $1.5 \%$ & $.1 \%$ & $.2 \%$ & $.4 \%$ \\
\hline \multirow{4}{*}{$\begin{array}{l}\text { Not in labor } \\
\text { force } \\
\text { Total }\end{array}$} & Count & 102462 & 51333 & 338093 & 155989 & 77718 & 526646 & 124728 & 72304 & 547548 & 144270 & 86085 & 684993 \\
\hline & $\%$ within & $9.9 \%$ & $10.4 \%$ & $8.9 \%$ & $11.9 \%$ & $10.9 \%$ & $9.9 \%$ & $8.7 \%$ & $7.9 \%$ & $8.0 \%$ & $7.1 \%$ & $7.2 \%$ & $7.7 \%$ \\
\hline & Count & 1034001 & 491663 & 3810875 & 1313327 & 713476 & 5339950 & 1427020 & 917264 & 6821149 & 2043521 & 1188894 & 8902060 \\
\hline & $\%$ within & $100.0 \%$ & $100.0 \%$ & $100.0 \%$ & $100.0 \%$ & $100.0 \%$ & $100.0 \%$ & $100.0 \%$ & $100.0 \%$ & $100.0 \%$ & $100.0 \%$ & $100.0 \%$ & $100.0 \%$ \\
\hline
\end{tabular}


Vasanthakumar N. Bhat / Journal of Social Sciences 10 (3): 97-103, 2014

Table 4. Personal property in the confederate, the slave and the union states by age in 1860 and 1870

\begin{tabular}{|c|c|c|c|c|c|c|}
\hline \multirow[b]{2}{*}{ Confed } & \multirow[b]{2}{*}{ Age category } & \multicolumn{2}{|l|}{1860} & \multicolumn{2}{|l|}{1870} & \multirow[b]{2}{*}{$\%$ change } \\
\hline & & $\mathrm{N}$ & Mean & $\mathrm{N}$ & Mean & \\
\hline \multirow[t]{5}{*}{ Confederate state } & $<=20$ & 259233 & 161.12 & 298414 & 13.68 & -91.51 \\
\hline & $>20$ and $<=30$ & 483774 & 1009.78 & 459982 & 246.02 & -75.64 \\
\hline & $>30$ and $<=40$ & 292450 & 2790.89 & 283511 & 559.55 & -79.95 \\
\hline & $>40$ & 377881 & 5940.63 & 453182 & 790.35 & -86.70 \\
\hline & Total & 1413338 & 2541.02 & 1495089 & 424.09 & -83.31 \\
\hline \multirow[t]{5}{*}{ Slave state (excconf) } & $<=20$ & 141009 & 16.82 & 171425 & 29.06 & 72.77 \\
\hline & $>20$ and $<=30$ & 249093 & 337.96 & 304748 & 300.81 & -10.99 \\
\hline & $>30$ and $<=40$ & 170114 & 1116.71 & 204681 & 764.94 & -31.50 \\
\hline & $>40$ & 194462 & 2048.24 & 291763 & 1287.36 & -37.15 \\
\hline & Total & 754679 & 894.19 & 972618 & 646.53 & -27.70 \\
\hline \multirow[t]{5}{*}{ Union states } & $<=20$ & 966652 & 9.85 & 1137909 & 11.19 & 13.60 \\
\hline & $>20$ and $<=30$ & 1798901 & 243.28 & 2056538 & 264.60 & 8.76 \\
\hline & $>30$ and $<=40$ & 1277552 & 583.47 & 1543787 & 838.65 & 43.73 \\
\hline & $>40$ & 1674836 & 988.01 & 2452532 & 1607.09 & 62.66 \\
\hline & Total & 5717941 & 497.97 & 7190767 & 805.62 & 61.78 \\
\hline \multirow[t]{5}{*}{ Total } & $<=20$ & 1366895 & 39.26 & 1607748 & 13.56 & -65.46 \\
\hline & $>20$ and $<=30$ & 2531769 & 399.06 & 2821269 & 265.48 & -33.47 \\
\hline & $>30$ and $<=40$ & 1740117 & 1006.59 & 2031980 & 792.29 & -21.29 \\
\hline & $>40$ & 2247179 & 1912.58 & 3197477 & 1462.16 & -23.55 \\
\hline & Total & 7885959 & 902.04 & 9658474 & 730.54 & -19.01 \\
\hline
\end{tabular}

Table 5. Tobit regression parameters with value of personal property of the whites over 15 years of age as a dependent variable

\begin{tabular}{|c|c|c|c|c|}
\hline \multirow[b]{2}{*}{ Parameter } & \multicolumn{2}{|l|}{1860} & \multicolumn{2}{|l|}{1870} \\
\hline & Estimate & $\mathrm{t}$ Value & Estimate & $\mathrm{t}$ Value \\
\hline Intercept & -5365.0 & -352.22 & -4922.9 & -281.73 \\
\hline Confederate states & 3256.4 & 376.15 & -623.9 & -59.99 \\
\hline Slave states (excconfsta) & 924.3 & 81.42 & 159.2 & 13.13 \\
\hline Union & 0.0 & 0.00 & 0.0 & 0.00 \\
\hline Age $<20$ & -13107.0 & -653.73 & -16492.0 & -660.17 \\
\hline Age $20-29$ & -4250.3 & -523.83 & -5124.6 & -572.36 \\
\hline Age $30-39$ & -1384.7 & -165.45 & -1481.8 & -163.81 \\
\hline Over 39 & 0.0 & 0.00 & 0.0 & 0.00 \\
\hline Not reported & -545.4 & -25.76 & -4265.2 & -171.28 \\
\hline Agriculture & 4148.6 & 257.22 & 2715.7 & 144.38 \\
\hline Forestry \& fishing & 1209.1 & 17.16 & -1616.5 & -19.06 \\
\hline Mining, quarrying, oil extraction & -2021.0 & -55.83 & -3617.5 & -91 \\
\hline Construction & 427.7 & 18.69 & -2342.1 & -90.72 \\
\hline Manufacture & 655.7 & 28.03 & -2027.2 & -78.57 \\
\hline Trade & 1054.3 & 48.93 & -853.0 & -34.59 \\
\hline Transportation & -423.4 & -15.79 & -3316.9 & -116.13 \\
\hline Utilities (water, telegraph etc) & -1580.3 & -7.35 & -2193.9 & -20.26 \\
\hline Services & -38.5 & $-1.48 *$ & -2145.0 & -73.27 \\
\hline Public Admn\& Post office & 293.5 & 6.32 & -2280.8 & -49.46 \\
\hline Non-classified & 450.3 & 16.21 & -3012.7 & -76.22 \\
\hline Not in labor force & 0.0 & 0.00 & 0.0 & 0.00 \\
\hline Occupational income score & 155.2 & 339.01 & 191.0 & 374.96 \\
\hline _Sigma & 7761.9 & 2857.64 & 9167.8 & 2968.14 \\
\hline Number of observations & 74542.0 & & 94888.0 & \\
\hline
\end{tabular}

*Not statistically significant at the 0.05 level. All other variables statistically significant at the 0.01 level 


\section{CONCLUSION}

This study provides an analysis of pre and post economic conditions of people at the individual level using census data for the decades ending 1850 to 1880. Our analysis indicates that involvement in farming by white males went down between 1860 and 1870 and it reached the 1850 level by 1880 in the Confederate states. This is in spite of the fact that white males in the South lost ownership of slaves who were used in the farms. There was a devastation of personal property between 1860 and 1870 for all white males in the Confederate and Slave states whereas they grew modestly for the Union states.

\section{REFERENCES}

Barro, R.J. and X. Sala-i-Martin, 1995. Economic Growth. 1st Edn., McGraw Hill, New York.

Beard, C. and M. Beard, 1927. The Rise of American Civilization. Two volumes.Macmillan, New York.

Cochran, T.C., 1961. Did the civil war retard industrialization? Mississippi Valley Historical Rev., 48: 197-210. DOI: 10.2307/1902511

Collier, P. and A. Hoeffler, 1998. On the economic causes of civil war. Oxford Econ. Papers, 50: 56373. DOI: $10.1093 /$ oep/50.4.563

Djankov, S., E. Miguel, Y. Qian, G. Roland and E. Zhuravskaya, 2005. Who are Russia's entrepreneurs? J. Eur. Econ. Assoc., 3: 587-597. DOI: 10.1162/jeea.2005.3.2-3.587

Engerman, S., 1966. The Economic Impact of the Civil War. In: Explorations in Entrepreneurial History, Spring-Summer, pp: 176-199.

Fosu, A.K. and P. Collier, 2005. Post-Conflict Economies in Africa. 1st Edn., PalgraveMacmillan, New York, ISBN-10: 140394346X, pp: 288.

Ghobarah, H., P. Huth and B. Russett, 2003. Civil wars kill and maim people-long after the shooting stops. Am. Political Sci. Rev., 97:189-202. DOI: 10.1017.S0003055403000613

Gallman, R.E., 1966. Gross national product in the United States, 1834-1909. In: Employment and Productivity in the United States after1800, Brady, D.S. (Ed.), Output, Columbia University Press, New York.

Goldin, C. and F. Lewis, 1975. The economic cost of the American civil war: Estimates and implications. J. Economic History, 35: 299-326.

Hacker, L., 1940. The Triumph of American Capitalism: The Development of Forces in American History to the End of the Nineteenth Century. 1st Edn., Columbia University Press, New York.
Hacker, D.J., 2011. A census-based count of the civil war dead. Civil War History, 57: 307-345. DOI: 10.1353/cwh.2011.0061

Haines, M.R., 2000. The Population of the United States, 1790-1920. In: The Cambridge Economic History of the United States, Engerman, S.L. and R. Gallman (Eds.), Cambridge University Press, New York, ISBN-10: 0521553083, pp: 143-206.

Jaworski, T., 2009. War and wealth: economic opportunity before and after the Civil War, 18501870. Economic History Working Papers, London School of Economics.

Montalvo, J.G. and M. Reynal-Querol, 2007. Fighting against malaria: Prevent wars while waiting for the "miraculous" vaccine. Rev. Econom. Stat., 89: 16577. DOI: $10.1162 /$ rest.89.1.165

Murdoch, J. and T. Sandler, 2004. Civil wars and economic growth: Spatial dispersion. Am. J. Political Sci., 48: 138-51. DOI: 10.1111/j.0092-5853.2004.00061.x

Przeworski, A., M. Alvarez, J. Cheibub and F. Limongi, 2000. Democracy and Development: Political Institutions and Well-Being in the World, 1950-1990. 1st Edn., Cambridge University Press, Cambridge, United Kingdom, ISBN-10: 0521793793, pp: 340.

Organski, A.F.K. and J. Kugler, 1981. The War Ledger. 1st Edn., University of Chicago Press, Chicago, ISBN-10: 0226632806, pp: 299.

Ransom, R.L. and R. Sutch, 2001. One Kind of Freedom: The Economic Consequences of Emancipation. 2nd Edn., Cambridge University Press, New York, ISBN-10: 0521791693, pp: 486.

Ruggles, S., J.T. Alexander, K. Genadek, R. Goeken and M.B. Schroeder et al., 2010. Integrated Public Use Microdata Series: Version 5.0. University of Minnesota, Minneapolis.

Russell, W.M., 2001. The economic impact of the American civil war: An empirical examination. George Mason University.

Salsbury, S., 1967. The Effect of the Civil War on American Industrial Development. In: The Economic Impact of the American Civil War andreano, R. (Ed.), Schenkman Publishing Co., New York.

Soares, R., 2006. The welfare cost of violence across countries. J. Health Econom., 25: 821-46. DOI: 10.1016/j.jhealeco.2005.10.007

Steckel, R.H., 1989. Poverty and Prosperity: A Longitudinal Study of Wealth Accumulation, 1850-1860. 1st Edn., National NBER, Cambridge, MA., pp: 30.

WB, 2003. Breaking the Conflict Trap: Civil War and Development Policy. World Bank Publications, ISBN-10: 0821386417. 